\title{
La proyección económica de la Iglesia en el mundo rural español durante el Antiguo Régimen
}

\author{
MAXIMIIJANO BARRIO GOZALO \\ Universidad de Valladolid
}

Antes de centrarme en el tema debo presentar a los protagonistas: el mundo rural y la Iglesia. Después, analizaré la proyección económica del segundo sobre el primero, para terminar examinando la crítica que diferentes grupos sociales hacen contra el poder económico de la Iglesia y los impuestos que pesan sobre el mundo rural hasta conseguir su abolición.

\section{LOS PROTAGONISTAS}

\subsection{El campesinado}

Se trata del grupo social más numeroso (superior al 80\%), aunque su papel social dista mucho de su peso numérico. Unos pocos, los propietarios y grandes arrendatarios, designados con el nombre de "labradores". en la documentación de la época, dominan la vida rural a escala local y no tienen problemas de subsistencia. Otros, más numerosos, podían equibrar balances en una coyuntura normal, pero no si se repetían los años de malas cosechas. Y la mayoría estaba constituido por los jornaleros, que apenas podian sobrevivir con un jornal que, con suerte cobraban dos tercios del año y que, a mediados del siglo XVIII, no llegaban a los cuatro reales, ya que lo general es que fuera de dos o tres (1).

(1) Sobre el mundo rural son muchos los estudios de carácter regional que se han publicado en los últimos años. Entre ellos, me limito a mencionar los de F. BRUMONT: Campo y campesinos de Castilla la Vieja en tiempos de Felipe II, Madrid, 1984; A. GARCIA SANZ: Desarrollo y crisis del antiguo régimen en Castilla la Vieja, Madrid, 1977; A. HERRERO GARCIA: El Aljarafe sevillano durante el antiguo régimen, Sevilla, 1981; NOEL SALOMON: La vida rural castellana en la época de Felipe II, Barcelona, 1974; D. WASSBERG: Tierra y sociedad en Castilla (Señores, "poderosos" y campesinos en la España del Siglo XVD), Barcelona, 1986; VV.AA.: Actas del Congreso de Historia Rural. Siglos XVI-XIX, Madrid, 1984; VV.AA.: Estructuras agrarias y reformismo ilustrado en la España del siglo XVIII, Madrid, 1989; B. YUN CASALILLA: Sobre la transición del feudalismo al capitalismo en Castilla. Economía y sociedad en Tierra de Campos (1500-1830), Salamanca, 1987; etc. 
Pero ¿cómo viven los campesinos? Un autor de finales del siglo XVII les describe con estas palabras:

"Uno puede ver ciertos animales, machos y hembras, esparcidas por los campos, negros, lividos y quemados por el sol, encadenados a la tierra que cavan y trabajan con increíble obstinación. Parece que puedan hablar; cuando se incorporan muestran un rostro humano y, en efecto, son hombres. Por las noches se retiran a sus escondrijos donde viven con pan, agua y raíces. Sufren por otros el dolor de sembrar, labrar y cosechar para vivir, y no obstante no merecen la escasez del pan que ellos mismos han sembrado" (2).

Según el vecindario de 1747 , el 60 por 100 de la población rural de la antigua provincia de Segovia es pobre o tiene dificultades para sobrevivir (3). Veamos algunos ejemplos:

-Los 50 vecinos del pueblo de Campo de San Pedro "viven y se mantienen de una corta labranza de pan, pensionada con la renta que anualmente pagan, no comiendo ni vistiendo más que lo necesario para no morirse de hambre o de frío".

- "De los 106 vecinos de Cogeces del Monte, 7 tienen para comer un año, sin sobrarles nada; 18 sólo para tirar, los 60 jornaleros lo pasan bastante mal, y los 21 restantes son pobres de solemnidad".

-Por último, en Fuentélcesped la mayor parte del pueblo se compone de jornaleros que trabajan en las viñas, y "en su vejez se hallan tan pobres que, no bastando la caridad para socorrerles, viven cayéndose muertos por la calle".

Esta situación de pobreza se refleja también en la vivienda y en la alimentación: -En Lastras del Pozo "las cosas son tan reducidas que las más sólo constan de un cuarto, cocina y portal, sin más luz que la que suministra éste, teniendo abierta la puerta. Y en esta casa tiene que habitar el matrimonio con los cuatro o seis de familia".

-En Castillejo de Mesleón, "donde la gente es pobrísima, su alimento ordinario no excede de unas verduras con algo de tocino, el que lo tiene, y unas sopas de pan, que con dificultad verán alguna vez el aceite".

$Y$ a pesar de una situación tan poco halagueña, el campesinado tenía que pagar derechos y rentas al señor, impuestos al Estado y diezmos, primicias y voto de Santiago a la Iglesia, pues como decía González de Cellorigo "uno que labra ha de sustentar a si y al señor de la heredad, y al señor de la renta, y al cogedor del diezmo, y al recaudador del censo, y a los demás que piden" (4).

(2) J. de la BRUYERE: Les caracteres ou les moeurs de ce siècle, 1689, cap. 11. Descripciones similares encontramos en Fray Benito de, PEÑALOSA, Libro de las cinco excelencias del español. Pamplona, 1629.

(3) Archivo Diocesano de Segovia (ADSg), Est. 4, leg. 6. Más información sobre la vida de la población rural de la diócesis de Segovia se puede ver en los informes que los curas envían al obispo en 1798 (AGSg, Est. 4, leg. 10). Las Relaciones topográficas de los pueblos de España, que se conservan en la Biblioteca del Monasterio del Escorial (J-12, 13, 14, 15, 16, 17 y 18) y que fueron utilizadas por Noel Salomón (La vida rural castellana en tiempos de Felipe II), aportan abundantes datos sobre el mundo rural de Castilla la Nueva a finales del siglo XVI.

(4) Memorial de la política necesaria y útil restauración de la república en España..., Valladolid, 1600. 


\subsection{La Iglesia y los eclesiásticos}

La población eclesiástica, a pesar del espectacular aumento que experimenta en el siglo XVII (en torno al 75 por 100) sólo representa un 1,5 por 100 de la población española en la época moderna. Sin embargo tiene un inmenso poder económico y controla los comportamientos religiosos e ideológicos del resto de la población.

Aunque es relativamente fácil poder conocer el número de eclesiásticos de una localidad o de una diócesis a través de la documentación que se guarda en los archivos diocesanos, todavía hoy resulta difícil saber con cierta precisión la evolución de la población eclesiástica a nivel del Estado, pues para ello hay que recurrir a los recuentos generales de población con los problemas técnicos conlleva.

Todos los estudiosos están de acuerdo en afirmar que el número de eclesiásticos aumenta 'considerablemente a lo' largo del seiscientos, pero ninguno se atreve a precisar el volumen de este incremento. A la hora de dar cifras sobre la población eclesiástica nos encontramos con que para el siglo XVII no se cuenta con ninguna estadística válida y fiable, y para el XVI sólo con la de 1591. Esto me obliga a utilizar las cifras que aporta el censo de 1591, completadas con las referentes a la Corona de Aragón, País Vasco y Navarra, a fin de disponer de un término "a quo" que se pueda poner en relación con el término "ad quem" de los censos de la segunda mitad del setecientos.

El censo de 1591 (5), estudiado por Felipe Ruiz Martín (6), se circunscribe a la Corona de Castilla y especifica el número de clérigos seculares, religiosos y monjas, arrojando un total de $\mathbf{7 4 . 1 5 3}$ eclesiásticos, a los que habría que añadir otros 16.932 de los territorios de la Corona de Aragón, País Vasco y Navarra.

Para la primera mitad del setecientos ocurre algo similar a la centuria anterior, pues el llamado Censo de Campoflorido (7), referido a la etapa final de la guerra de Sucesión, ni es digno de crédito ni contabiliza los eclesiásticos. No obstante, a través de los datos que aporta Jerónimo Ustáriz (8), se puede atisbar que, a pesar de la disminución de la población, el clero permaneció "sin detrimento casi por doquier en la misma cantidad" y, en su opinión, el número de eclesiásticos, junto con sus familiares, dependientes y criados, constituían la trigésima parte de la población. Ahora bien, si descontamos las personas que de algún modo están vinculadas a los eclesiásticos, éstos quedan reducidos a un porcentaje cercano al 2 por 100 de la población, cifra muy similar a la que ofre-

(5) Archivo General de Simancas (=AGS), Dirección General del Tesoro, leg. 1.301.

(6) "La población española al comienzo de los tiempos modernos", en Cuadermos de Historia, 1 (1967) 189-202; y "Demografia eclesiástica hasta el siglo XIX", en Diccionario de Historia Eclesiástica de España, II, Madrid, 1972, pp. 685-723.

(7) Ha sido estudiado por C. BUSTELO GARCIA, "El vecindario general de España de 1712-1721 o Censo de Campoflorido, I", en Revista Internacional de Sociología, 32 (1973) 83-104; II, 33 (197.4) 7-36

(8) Theoria y práctica de comercio y navegación, Madrid, 1724, pp. 34-39. 
ce para Cataluña la Relación general del vezindario de el Principado de Cataluña de 1718(9).

Para los años centrales del setecientos, en cambio, disponemos de varios censos que permiten conocer con bastante verosimilitud la población eclesiástica española. El Censo de Ensenada, elaborado a partir de la información que aportan los "Libros de familia de las respuestas particulares", realizados entre 1749 y 1752 , constituye una fuente demográfica de primer orden para las veintidós provincias de la Corona de Castilla (10). Por lo que se refiere al ámbito eclesiástico, da cuenta de los edificios religiosos (catedrales, colegiatas, parroquias, ermitas y conventos) y similares (hospitales y colegios), así como de la población eclesiástica que reside en cada una de ellos. Elaborados los datos, el número de eclesiásticos asciende a 116.461, lo que representa el 1,77 por 100 de la población de las veintidós provincias de Castilla. Si a esta cifra sumamos los 34.757 eclesiásticos, descontados los servidores laicos, que Martín Loynaz consigna a la Corona de Aragón en 1747 (11), más los aproximadamente 10.607 que existen en Canarias, País Vasco y Navarra (12), resulta un total de 161.825 eclesiásticos, iguales al 1,74 por 100 de la población.

Unos años después, en 1768, se realiza el Censo de Aranda que abarca la totalidad del territorio español y se ajusta a las demarcaciones diocesanas. Las cifras, que al proceder de fuentes eclesiásticas se presumen bastante fiables, ano$\tan 65.687$ miembros del clero secular y 82.118 del regular, que suman un total de 147.805 eclesiásticos, equivalentes al 1,46 por 100 de la población (13). La comparación con el censo anterior muestra una disminución de 13.016 eclesiásticos, pertenecientes casi en su totalidad $(86,31 \%)$ al clero regular, lo que puede ser debido a la expulsión de los jesuitas (14) y a que este censo no contabiliza la población eclesiástica de las jurisdicciones "vere nullius" (15).

(9) Según esta Relación, que se encuentra en la BN. de Madrid, ms. 2.274, y ha sido publicada por J. IGLESIAS, Estadistiques de població de Catalunya el primer vicenni del segle XVIII, Barcelona, 1974, el personal eclesiástico de Cataluña tras la guerra de Sucesión asciende a 9.841 miembros, divididos en 5.715 clérigos, 2.916 frailes y 1.210 monjas. Ello quiere decir que la familia eclesiástica representa cerca del 2,5 por 100 de la población, estimada por el propio censo de 1718 en 389.960 habitantes. Porcentaje que Roberto Fernández ("La clerecía catalana en el setecientos", en Església $i$ societat a la Catalunya del s. XVIII, I, Cervera 1990 , p. 48) rebaja considerablemente, al decirnos que "tras la guerra de Sucesión el clero catalán no representa más allá del 2 por 100 de la población".

(10) En el AGS, Dirección General de Rentas, 1. ${ }^{a}$ Remesa, leg. 1980, se encuentran las cifras totales para veintiuna de las veintidós provincias. La que falta, Toledo, conserva su censo en el Archivo Histórico Nacional ( $=\mathrm{AHN}$ ), Hacienda, libro 7.497.

(11) J. SAEZ MARIN: Datos sobre la Iglesia Española Contemporánea, Madrid, 1975, pp. 156-157.

(12) Este número se ha calculado a partir de los censos de Aranda (1768) y de Floridablanca (1787).

(13) Los datos se han tomado de J. SAEZ MARIN: Datos sobre la Iglesia..., pp. 163, 233 y 289.

(14) Según el catálogo confeccionado en octubre de 1766 por el P. Luengo (publicado por C. GOMEZ RODELES: Vida del célebre misionero P. Pedro Calatayud de la Compañía de Jesús y relación de sus apostólicas empresas en los reinos de España y Pontugal, 1689-1773, Madrid, 1982, pp. 545-546), los jesuitas sumaban 2.746 miembros en España; T. EGIDO: "La expulsión de los jesuitas de España", en Historia de la Iglesia de España, dir. por García Villoslada, IV, Madrid, 1979, pp. 756-759, ofrece datos precisos sobre el número y calidad de los expulsos.

(15) Esto no sucede en la diócesis de Segovia, según ha puesto de manifiesto M. BARRIO GOZALO: Estudio socio-económico de la Iglesia de Segovia en el siglo XVII, Segovia, 1982, pp. $49-50$. 
El Censo de 1787 consigna unas cifras algo inferiores al anterior, lo que resulta más significativo. La población eclesiástica asciende a 143.600 individuos, iguales al 1,31 por 100 de la población, y está compuesta por 70.170 miembros del clero secular y 73.430 del regular (16).

El último recuento realizado en el siglo XVIII, el año 1797 permite conocer con gran precisión la distribución del clero secular y hasta bien entrado el presente siglo no se hallará otra estadística tan completa. Las cifras globales suman 144.212 eclesiásticos y apenas varía respecto al cómputo anterior (17).

Por último, los datos de 1835 proceden de las averiguaciones que efectúa la Real Junta Eclesiástica y muestran un fuerte descenso de los efectivos eclesiásticos tanto en términos absolutos como relativos (18). En el cuadro primero se presenta una evaluación aproximativa de la población eclesiástica española en el periodo estudiado:

CUADRO 1

La población eclesiástica

\begin{tabular}{ccclcc} 
Año & \multicolumn{2}{c}{ Clero } & \multicolumn{2}{c}{ Total } & $\begin{array}{c}\text { \% de la } \\
\text { Población }\end{array}$ \\
\cline { 2 - 5 } & Secular & Regular & Número & Indice & \\
\hline 1591 & 40.599 & 50.486 & 91.085 & $\mathbf{1 0 0 ; 0 0}$ & 1,12 \\
1700 & - & - & $160.000(19)$ & $\mathbf{1 7 5 , 6 6}$ & 2,00 \\
1752 & 66.691 & 95.134 & 161.825 & $\mathbf{1 7 7 , 6 6}$ & 1,74 \\
1768 & 65.687 & 82.118 & 147.805 & $\mathbf{1 6 2 , 2 7}$ & 1,46 \\
1787 & 70.170 & 73.430 & 143.600 & 157,65 & 1,31 \\
1797 & 70.840 & 73.372 & 144.212 & 158,33 & 1,25 \\
1835 & 41.151 & 52.906 & 94.057 & 103,26 & 0,81
\end{tabular}

Los datos del cuadro anterior permiten establecer las siguientes conclusiones: - La población eclesiástica está constituida en un 45,38 por 100 por miembros del clero secular y en un 54,62 por 100 del regular; es decir, los religiosos $(34,51 \%)$ y las monjas $(20,11 \%)$ superan ligeramente a los primeros.

-A lo largo del seiscientos los eclesiásticos aumentan sus efectivos en torno al 75 por 100 y su representación dentro del conjunto de la población sube del 1,12 por 100 a cerca del 2 por 100 (20). Durante la primera mitad del setecientos asistimos a una situación de estancamiento en lo referente a las cifras absolutas, y a una pequeña disminución en relación con la población total. A partir de mediados de siglo, el número de eclesiásticos empieza a disminuir en términos absolu-

(16) J. SAEZ MARIN: Datos sobre la Iglesia..., pp. 164-165, 234-235 y 296-297.

(17) Ibídem, pp. 167-168, 238 y $298-305$.

(18) Ibídem, pp. 200, 258 y 311-327.

(19) Esta cifra, deducida de los datos que aporta Ustáriz (Theoria y práctica de comercio..., pp. 34-39) y de la Relación general del vezindario de el Principado de Cataluña de 1718 antes citada, sólo tiene un valor referencial.

(20) Mayor aumento se da en Italia, pues según afirma X. TOSCANI: "Il reclutamento del clero (secoli XVI-XIX)", in Storia d'Italia, Annali 9. La Chiesa e il potere politico, Torino, 1986, pp. 575-628, desde finales del siglo XVI hasta mediados del XVIII la población eclesiástica italiana se duplica o triplicà. 
tos y, sobre todo, relativos, pues la representación de los eclesiásticos dentro del conjunto de la población, que en 1752 supone el 1,74 por 100, baja al 1,25 en 1797 y cae hasta el 0,81 en 1835 .

Por otra parte, si nos fijamos en el comportamiento que tiene la población eclesiástica en la Corona de Castilla, para cuyo territorio disponemos de información más completa (ver cuadro 2), llegamos a la conclusión de que, a lo largo de los 161 años que separan los censos de 1591 y de Ensenada (1752), el número de eclesiásticos aumenta de forma generalizada en las veintidós provincias de Castilla en un 57,05 por 100. Pero este incremento no es uniforme, pues difiere sensiblemente de unas regiones a otras. En algunas (Murcia y Galicia) supera el 150 por 100, en otras (Extremadura, Andalucía y Castilla la Vieja) se sitúa entre el 50 y el 99 por 100, y en Castilla la Nueva y León apenas llega al 20 por 100.

Es más, si examinamos su comportamiento en relación con el movimiento general de la población, observamos que el aumento es todavía mayor, ya que se eleva al 58,03 por 100. Pero aquí el movimiento tampoco es uniforme, porque su representación depende de la evolución que, durante el período 1591-1752, observan la población global y la eclesiástica, que es muy diferente de unas regiones a otras.

\section{CUADRO 2 \\ Evolución del número de eclesiásticos y su relación con el movimiento general de la población}

\begin{tabular}{|c|c|c|c|c|c|c|}
\hline \multirow[b]{2}{*}{ Región } & \multicolumn{3}{|c|}{ Número de eclesiásticos } & \multicolumn{3}{|c|}{$\%$ población total } \\
\hline & $\begin{array}{l}1591 \\
\text { Núm. }\end{array}$ & $\begin{array}{l}1752 \\
\text { Núm. }\end{array}$ & $\begin{array}{c}\text { Diferencia } \\
\text { en } \%\end{array}$ & $\begin{array}{c}1591 \\
\%\end{array}$ & $\begin{array}{c}1752 \\
\%\end{array}$ & $\begin{array}{c}\text { Diferencia } \\
\text { en } \%\end{array}$ \\
\hline Andalucía & 18.547 & 32.980 & $+77,81$ & 1,39 & 2,02 & $+45,32$ \\
\hline Castilla la N. & 15.559 & 17.308 & $+11,24$ & 1,08 & 1,72 & $+\quad 59,25$ \\
\hline Castilla la V. & 12.686 & 21.252 & $+67,52$ & 1,18 & 2,12 & $+79,66$ \\
\hline Extremadura & 4.751 & 9.227 & $+95,68$ & 0,84 & 1,97 & $+134,52$ \\
\hline Galicia & 4.711 & 11.867 & $+151,57$ & 0,74 & 0,91 & $+22,97$ \\
\hline León & 16.184 & 19.467 & $+\quad 20,28$ & 1,11 & 1,67 & $+50,54$ \\
\hline Murcia & 1.715 & 4.360 & $+154,22$ & 1,19 & 1,62 & $+36,13$ \\
\hline TOTAL & 74.153 & 116.461 & $+57,05$ & 1,12 & 1,77 & $+58,03$ \\
\hline
\end{tabular}

Por último, la población eclesiástica aparece distribuida de forma muy desigual, tanto en lo que se refiere a los ámbitos provinciales como por lo que mira a los medios rural y urbano. Por ejemplo, si examinamos el Censo de Ensenada (1752) se observa que, mientras en las provincias de Valladolid y Sevilla los eclesiásticos representan el 2,94 y el 2,29 por 100 de la población, en Galicia sólo suponen el 0,91 por 100 y en las de Cuenca y León el 1,01 por 100, situándose en un término medio las de Soria $(1,46 \%)$, Murcia $(1,62 \%)$ y Segovia $(1,72 \%)$. Pero donde la presencia de los eclesiásticos alcanza los niveles más altos es en las ciudades: 11,09 por 100 en Vallądolid, 8,67 por 100 en Segovia, 5,33 por 100 en Ciudad Real, etc. Esta concentración de eclesiásticos en el medio urbano, sobre todo de regulares, es consecuencia del proceso de urbanización que estos últimos inician en la segunda mitad del quinientos y culminan en el seiscientos. 
Sin embargo, aunque los eclesiásticos: sólo representan el 1,50 por 100 de la población, tienen un inmenso poder económico, pues su participación en la renta nacional supera el 10 por 100. El Estado de cuentas que los procuradores de la Congregación del Clero de los reinos de Castilla envían a Roma en 1630, para defenderse de la presión fiscal a que se veían sometidos en los años de la guerra de los Treinta Años, muestra que las rentas eclesiásticas fijas de la Corona de Castilla (excluidas las del clero regular) representan el 9,21 del producto nacional (21).: Un siglo después, el Catastro de Ensenada permite conocer, tanto a nivel local como provincial o nacional, la riqueza de la Iglesia con mayor precisión y se puede afirmar que a mediados del setecientos los ingresos fijos de la Iglesia de Castilla se aproximan al 13,17 por 100 de la renta nacional (22).

\section{PROYECCION ECONOMICA DE LA IGIESIA EN EL MUNDO RURAL}

La Iglesia está presente en la economía del mundo rural a través de las propiedades que posee, de los diezmos, primicias y voto de Santiago que percibe, y de los derechos que cobra por las prestaciones religiosas que ofrece. Todo esto sustrae al mundo campesino de una importante riqueza que va a parar a la Iglesia.

Todavía hoy resulta difícil evaluar la riqueza que la Iglesia española controla en el antiguo régimen, aụnque es indudable que su cuantía era muy grande. Conocemos bastante bien las rentas de alguna institución eclesiástica. En concreto de las mesas episcopales (23), de algunos cabildos catedrales (24), de muchos

(21) ASV, Misc. Arm. I, vol. 90, F. 246: Valor de todas las rentas eclesiásticas y seglares de los reinos de la Corona de Castilla, reducidos los frutos de la tierra a dinero, y en particular se declara el de los cinco arzobispos y 31 obispados... 1630.

(22) Datos tomados del GRUPO'75: La economía del antiguo régimen. La "renta nacional" de la Corona de Castilla, Madrid, 1977, pp. 189-203.

(23) M. BARRIO 'GOZALO, "Los obispos de Castilla la Vieja, 1600-1840", en Antbologica Annua, 2829 (1981-82), 100-138; ID: "II: Los obispos del reino de León", en Ibídem, 30-31 (1983-84), 242291; ID: "III: Los obispos del reino de Galicia", en Ibidem, 32 (1985), 58-107; ID, "IV: Los obispos de Castilla la Nueva y Extremadura", en Ibídem, 33 (1986) 220-302; ID: "V: Los obispos de Andalucía", en Ibídem, 34 (1987) 84-188; ID: "VI: Los obispos de Pamplona, 1556-1834", en Ibidem, 38 (1991) 79-106; "VII: Los obispos de Cartagena-Murcia", en Ibidem, 39 (1992) 141-166; ID, "La economía de las mitras catalanas en la segunda mitad del siglo XVIII y su relación con el conjunto español", en Pedralbes, 8-II (1988) 447-457; ID, "El poder económico de los obispos castallanos al final del antiguo régimen", en Iglesia, Sociedad y Estado en España, Francia e Italia (ss. XVIII al XX), Alicante, 1991, pp. 91-105; e ID, "La economía de los obispos en la España del antiguo Régimen (1556-1834)", en Fra spazio e tempo. Studi in onore di Luigi De Rosa, I, Napoli, 1995, pp. 52-75; A. DOMINGUEZ ORTIZ: "Las rentas de los prelados de Castilla en el siglo XVII", en Anuario de Historia Económica y Social, 3 (1970), 437-464; e ID: "Las rentas episcopales de la Corona de Aragón en el siglo:XVII", en Agricultura, comercio colonial y crecimiento económico en la España contemporánea, Barcelona, 1975, pp. 14-43; y CH. HERMANN: L'Eglise d'Espagne sous le patronage royal (1476-1834), Madrid, 1988, pp. 149-189.

(24). Entre ellos se pueden mencionar los de L.C. GARCIA FIGUEROA: La economía del Cabildo salmantino del siglo XVIII, Salamanca, 1989; J.M. LATORRE CIRLA, Economía y religión. Las rentas de la Catedral de Huesca y su distribución social (siglos XVI-XVIII), Zaragoza, 1992; I. LOPEZ CELADA: Evolución de las rentas del Cabildo de la Catedral de Toledo en el último cuarto del siglo XVI, Toledo, 1982; R. VAZQUEZ LESMES: Córdoba y su Cabildo catedralicio en la modernidad, Córdoba, 1987; etc. 
conventos y monasterios (25), y de algunas diócesis (26). Es cierto que las síntesis de Quintín Aldea (27), Domínguez Ortiz (28) y, sobre todo, la de Bernal y López Martín (29) ofrecen una visión aproximativa y de gran interés sobre la indudable riqueza de la Iglesia española.

La evaluación más completa de los ingresos del clero procede del Catastro de Ensenada. Realizado a mediados del siglo XVIII, sólo concierne a las veintidós provincias de la Corona de Castilla, sin que se disponga de nada similar para la Corona de Aragón y Navarra, aunque no hay motivos para creer que en estas regiones la situación fuera substancialmente distinta. La documentación catastral describe los bienes del clero, distinguiendo entre las propiedades de la Iglesia como institución (eclesiástico-beneficial) y las que posee el clero a título particular (eclesiástico-patrimonial), y permite conocer los ingresos del clero, tanto los provenientes de las propiedades que posee como aquellos que dimanan de otras fuentes de riqueza (30).

\subsection{Rentas de propiedades}

El patrimonio rústico que la Iglesia ha ido acumulando a lo largo de los siglos constituye uno de los capítulos más importantes de sus rentas (31). A

(25) Como los estudios sobre monasterios concretos son muy numerosos, me limito a indicar tres obras que abarcan un ámbito geográfico más amplio: A. ATIENZA LOPEZ: Propiedad, explotación y rentas. El clero regular zaragozano en el siglo XVIII, Zaragoza, 1988; E. LLOPIS AGELAN: Las economias monásticas al final del Antiguo Régimen en Extremadura, Madrid, 1980; y A.L. LOPEZ MARTIN: La economia de las órdenes religiosas en el Antiguo Régimen. Sus propiedades y rentas en el reino de Sevilla, Sevilla, 1992.

(26) Entre ellos, el ya citado de M. BARRIO GOZALO: Estudio socio-económico de la Iglesia de Segovia en el siglo XVIII; y también algunos capítulos de las obras de P. ANTON SOLE, Situación económica y asistencia social de la diócesis de Cádiz en la segunda mitad del siglo XVII, Cádiz, 1985, pp. 44-51; A. MORGADO GARCIA: Iglesia y Sociedad en el Cádiz del siglo XVIII, Cádiz, 1989, pp. 23-37, y P. PUEYO COLOMINA, Iglesia y Sociedad zaragozanas a mediados del s. XVIII, Zaragoza, 1991, pp. 339-367; asi como la colaboración de R. BENITEZ: "las rentas eclesiásticas del obispado de Málaga a mediados del siglo XVII", en Actas del I congreso de Historia de Andalucía, andalucía Modema (siglos XVI-XVII), I, Córdoba, 1978, pp. 119-129.

(27) Q. ALDEA: "El patrimonio eclesiástico", en Diccionario eclesiástico de España, III, Madrid, 1973, pp. 1890-1899.

(28) A. DOMINGUEZ ORTIZ: "Patrimonio y rentas de la Iglesia", en M. Artola (dir.), Enciclopedia de Itistoria de España, III, Madrid, 1988, pp. 75-126.

(29) A.M. BERNAL y A.L. LOPEZ MARTINEZ: "Las rentas de la Iglesia en el Antiguo Régimen", en Iglesia, Sociedad y Estado en España, Francia e Italia (ss. XVIII al XX), Alicante, 1992, pp. 15-40.

(30) Un resumen de sus datos, a nivel provincial, se encuentra en A. MATILLA TASCON: La única contribución y el Catastro de Ensenada, Madrid, 1947, pp. 185-529. No obstante, a la hora de interpretarlos, hay que tener en cuenta las matizaciones que hace J.M. PEREZ GARCIA: "Algunas reflexiones en torno a la utilización de la Unica", en Estudis d'Historia Agraria, 3. (1979), 101-137.

(31) Estos bienes, una vez que entraban en poder de la Iglesia por donación o por compra, se regían por leyes especiales que les vinculaban indefinidamente a la entidad eclesiástica, constituyendo lo que se conoce con el nombre de "manos muertas". La Novísima Recopilación, libro 1 , tít. 5, leyes 1 y 5 , recoge y sanciona la legislación existente sobre el tema. 
mediados del setecientos, la Iglesia posee en las veintidós provincias de Castilla el 14,74 por 100 de la superficie catastrada (ver cuadro 3). La mayor parte de este patrimonio $(12,35 \%)$ corresponde al eclesiástico beneficial, pues la de los eclesiásticos a título particular sólo representa el 2,39 por 100 .

CUADRO 3

Distribución de la propiedad y del producto bruto agricola

\begin{tabular}{lrrrr} 
& \multicolumn{2}{c}{ Tierras } & \multicolumn{2}{c}{ Producto } \\
\cline { 2 - 5 } Propietario & \multicolumn{1}{c}{ Medidas } & \multicolumn{1}{c}{$\%$} & \multicolumn{1}{c}{ Medidas } & \multicolumn{1}{c}{$\%$} \\
\hline Legos & 71.188 .910 & 85,26 & 816.666 .797 & 75,88 \\
Ecles. beneficial & 10.309 .464 & 12,35 & 209.713 .556 & 19,48 \\
Ecles. patrimonial & 1.994 .031 & 2,39 & 49.940 .854 & 4,64 \\
TOTAL & 83.492 .405 & 100,00 & $\mathbf{1 . 0 7 6 . 3 2 1 . 2 0 7}$ & 100.00
\end{tabular}

La distribución geográfica de esta propiedad presenta contrastes regionales muy acusados. La Iglesia tenía pocas posesiones en Galicia (5,76\%), donde también es baja la densidad de la población eclesiástica, y muchas en las zonas agrícolas del sur, sobre todo en Extremadura (21,50), privilegiada zona de pasto, y en Andalucía (18\%). En esta última la participación de la Iglesia alcanza su nivel más alto en el reino de Sevilla, donde posee el 20,12 por 100 de la superficie catastrada. En la submeseta norte su participación es relativamente menor, si se exceptúa la región leonesa $(14,84 \%)$, teniendo presente que mientras las propiedades eclesiásticas son escasas en la deprimida región montañosa astur-leonesa, alcanza porcentajes mucho más elevados en la provincia de Valladolid (19,14\%), especializada en el cultivo de la vid (32).

El análisis de la distribución del producto bruto agrícola pone de manifiesto que la Iglesia, aunque sólo posee el 14,74 por 100 de la superficie catastrada, se beneficia del 24,12 por 100 del producto agrícola (ver cuadro 3). Ante la falta de correlación entre tierra y producto es obligado concluir que las tierras de la Iglesia estaban mejor cultivadas o eran más fértiles. Parece más seguro que se tratase de lo último, tanto por los abundantes testimonios que conocemos como por los datos que ofrece el Catastro. La documentación catastral indica que la casi totalidad de las tierras de la Iglesia $(95,61 \%)$ tienen un aprovechamiento útil, tanto si se cultivan como si se dedican a pasto; en cambio las de legos sólo son productivas en un 74,35 por 100 . Es más, 'si se analiza la distribución de cultivos y superficie de pasto y monte, se observa que la superficie productiva propiedad de la Iglesia se dedica casi en su totalidad a tierras de cultivo y labor, siendo muy reducidas las extensiones de pasto y monte.

Los eclesiásticos utilizan dos formas de explotación en sus propiedades: el cultivo directo y el arrendamiento. El cultivo de una parte de sus fincas era normal entre los monasterios y conventos de religiosos. Sin embargo, la mayor parte de la tierra se arrendaba a colonos mediante diferentes tipos de contratos agrarios: simple contrato de arrendamiento a corto plazo, contratos de larga duración

(32) GRUPO'75: La economía del antiguo régimen..., p. 191. 
como son los foros o censos, contratos de aparcería y otras formas que variaban mucho de una zona a otra (33).

Por último se ha de precisar que del producto bruto agrícola obtenido en las propiedades de la Iglesia sólo una parte, próxima al 42,54 por 100, era percibida por los eclesiásticos. El 57,46 por 100 restante (ver cuadro 4) quedaba en manos de los colonos o se invertía en gastos productivos, necesarios para conseguir la cosecha.

\section{CUADRO 4 \\ Distribución del producto bruto agrícola de las tierras de la Iglesia}

\begin{tabular}{lrr} 
Concepto & Reales & \multicolumn{1}{c}{$\%$} \\
\hline Gastos productivos & 42.609 .289 & 16,41 \\
Utilidad de colonos & 106.583 .172 & 41,05 \\
Utilidad de eclesiásticos & 110.461 .949 & 42,54 \\
TOTAL & 259.654 .410 & 100,00
\end{tabular}

La ganadería constituye otro capítulo de las rentas eclesiásticas. De acuerdo con los datos del Catastro, el número de cabezas de ganado de distintas especies asciende a 2.725 .842 , lo que representa el 8,87 por 100 de las cabezas catastradas, y sus utilidades anuales se regulan en 17.629 .980 reales de vellón. Hay que notar, sin embargo, que el ganado lanar es el que predomina de manera hegemónica, tanto por el número de cabezas $(68,49 \%)$ como por las utilidades netas que reporta $(42,49 \%)$. La propiedad de este ganado está muy concentrada y son los grandes monasterios los que poseen las cabañas más numerosas. La del monasterio de Guadalupe asciende a 46.709 cabezas (34), y la de la Cartuja del Paular a 32.679 (35).

Por último, aunque el estado eclesiástico también detenta la propiedad de numerosos inmuebles de carácter urbano, generalmente viviendas, industrial y de servicios, que normalmente explota en régimen de alquiler y aportan a la Iglesia unas rentas anuales próximas a los 34.224 .036 reales de vellón al año, estos efectos tienen poca incidencia en el mundo rural, pues, a excepción de algunos molinos, se sitúan mayoritariamente en el ámbito urbano (36).

\subsection{Rentas en dinero}

La Iglesia española se beneficia también de los intereses que produzcan los censos y los juros, así como de las rentas enajenadas, derechos feudales, etc. El clero absorvía en Castilla las tres cuartas partes de los ingresos de los censos

(33) A modo de ejemplo diré que en la diócesis de Segovia los eclesiásticos sólo cultivan directamente el 26,47 por 100 de sus propiedades, mientras que el 73,53 por 100 restante lo ceden a campesinos en sistema de arriendo o censo. Cfr. M. BARRIO GOZALO: Estudio socio-económico..., pp. 82-83.

(34) Archivo Histórico Provincial de Toledo, Catastro, libro 896.

(35) Archivo Histórico Provincial de Segovia, Catastro, libro 310.

(36) Esta cantidad es la suma de las cifras que Matilla Tascón (La tinica contribución...) indica para cada una de las provincias. 
(72,89\%), cuyo importe ascendía a 27.916.164 reales de vellón (37); es decir, en manos de la Iglesia se encontraba el principal mecanismo de crédito de la época, que frecuentemente tendía a endeudar al campesino, por cuanto muchos censos, al ser préstamos hipotecarios, suponían una constante amenaza para el pequeño y mediano campesino, ya que los intereses que debían pagar estaban respaldados por la parcela de tierra que poseían y la falta de pago podía desembocar en su pérdida. Los procesos para apropiarse de la finca ante el impago de los réditos de los censos se ejecutan fundamentalmente en el siglo XVIII por monasterios y conventos como consecuencia del aumento del valor de la tierra y del incremento de los precios agrarios (38).

Aunque la Iglesia también se presenta como un importante prestamista del Estado, ya que disfruta del 75 por 100 de los intereses devengados por los juros, especie de títulos de deuda pública, cuya cuantía se aproxima a los 9.998 .082 reales de vellón, esta partida tiene mucha menos incidencia sobre el mundo rural (39).

Igualmente la Iglesia se beneficia de otros ingresos provenientes de rentas y oficios enajenados por la Corona y otras instituciones públicas, derechos señoriales, aniversarios, pensiones, etc., que el Catastro evalúa en 17.254.822 reales de vellón (40).

\subsection{Rentas decimales}

Los diezmos y primicias, escribía Carramolino a mediados del ochocientos, "han sido la fuente más abundante y el más pingüe caudal de toda la Iglesia" (41), y durante el antiguo régimen fue el ingreso más seguro del estado eclesiástico secular.

La exacción del diezmo se practicaba en el Antiguo Testamento y pasó a la Iglesia, primero como práctica voluntaria y, desde el siglo XIII con la publicación de las. Decretales, como impuesto obligatorio.

Por lo que se refiere a España, el primer texto que manifiesta la paga de diezmos en Castilla es el canon 2. del concilio de Palencia celebrado en 1129 . Los sínodos que se reunen en el siglo XIV recogen lo dispuesto' en las Decretales y dan normas precisas sobre su cobranza y la obligación moral de pagarles (42).

(37) Ibídem, pp. 429-444.

(38) J.U. GOMEZ ALVAREZ: "El censo redimible y' al quitar: un mecanismo real de transferencia de la propiedad", en Estudis, 6 (1977) 5-25; y LL. FERRER i ALOS: "Censals, vendes a carta de gracia i endeudament pagès al Bages (s. XVIII)", en Estudis d'Historia Agraria, 4 (1983), 101-128.

(39) Una interesante muestra de esta forma de inversión y su rentabilidad se puede ver en A.L. LOPEZ MARTINEZ: "Los juros de eclesiásticos. Participación de los conventos andaluces en la deuda pública castellana", en Revista de Historia Económica, X (1992), 433-450.

(40) Deducido de las cifras que ofrece Matilla Tascón (La única contribución...), aunque se ha descontado la cantidad referente a los derechos parroquiales que figura en algunas provincias, como Extremadura o' Madrid.

(41) J.M. CARRAMOLINO: La Iglesia española económicamente considerada, Madrid, 1852, p. 224.

(42) En casi todos los Sínodos diocesanos que se celebran a partir del siglo XIV se reserva un título o apartado a la obligación y forma de pagar los diezmos, según se puede observar en los 6 volúmenes del Symodicon Hispanum, que se han publicado hasta la fecha por la BAC, bajo la dirección de A. García García. Después del Concilio de Trento, los Sínodos que se celebran en los últimos años del siglo XVI y primera mitad del XVII dedican más atención a los diezmos y especifican con más detalle los productos sujetos al diezmo y a la forma de pagarlo. 
En el orden civil, la primera disposición que impone la obligación civil del pago de los diezmos se encuentra en el Fuero Real (1255) y en las Siete Partidas (1265), donde se reproduce la doctrina de las Decretales. Por último, la Novisima Recopilación dedica los títulos 6 y 7 del libro 1. a los diezmos. Esta legislación estuvo vigente hasta 1837, en que se suprimió la obligación legal civil de pagar diezmos a la Iglesia, y aunque esta disposición en nada afectaba al deber moral y religioso de abonar los diezmos, lo cierto es que paulatinamente se dejaron de pagar.

La percepción de los diezmos dio lugar a una complicada casuística y a no pocas disputas entre eclesiásticos y seglares, y también entre los propios eclesiásticos. En cada diócesis, la forma de diezmar se regulaba por las Constituciones Sinodales vigentes, de tal manera que las cartas circulares que los obispos publican sobre el tema a lo largo del período estudiado sólo buscan un mejor cumplimiento de la legislación vigente y corregir los abusos que se van introduciendo.

Toda persona, bajo pena de excomunión, tenía que pagar los diezmos y primicias de pan, vino, ganados y demás frutos y ganancias, según el derecho y la costumbre de cada lugar, sin reservar lo mejor para sí sino abonando el diezmo de la calidad que fuera, ni pudiendo aducir ignorancia, ya que todos los años los curas recordaban esta obligación en la misa dominical. Además, para evitar posibles fraudes en la manera de diezmar, estaba mandado que "todos diezmen en especie en las eras, sin sacar la simiente, gastos de labranza, salario de los criados, voto de Santiago ni otra cosa alguna, de diez uno y de cinco media, (...), midiendo los frutos con una medida colmada o rasada con toda igualdad. Y así mismo diezmen cada año en propia especie las lanas de los ganados, el queso y los corderos, etc." (43).

¿Quiénes estaban obligados a pagar el diezmo? Según la legislación civil y eclesiástica, todos los hombres, de cualquier estado, dignidad y condición que fueran, debían pagar los diezmos. Entre los productos sujetos al diezmo no había dudas sobre los llamados "diezmos mayores" (fundamentalmente cereales), pero sobre los "menudos" existían costumbres diversas. Es más, en algunos sitios se pagaba diezmo de productos no agrícolas, como la "barrilla" en Cartagena o la pesca en Galicia, y en otros, fundamentalmente al norte del Tajo, se exigía también el diezmo a los criados de sus soldadas.

Esta obligación universal de pagar el diezmo se fue recortando con el paso del tiempo por las exenciones concedidas por privilegio o impuestas por costumbre inmemorial a las propiedades de algunas instituciones eclesiásticas. Así, el monasterio de San Lorenzo del Escorial gozaba por privilegio papal de la "absoluta exención de pagar diezmos en todas sus tierras y haciendas". Esto explica que una cantidad importante de la cosecha de granos se sustraiga legalmente de esta obligación, que en el caso del obispado de Segovia asciende al 10 por 100. Estas exenciones estuvieron vigentes hasta 1796, en que una cédula real mandó observar el breve de Pío V, en el que se anulaban todas las exenciones de pagar diezmos concedidas a diferentes instituciones eclesiásticas por privilegio o costumbre inmemorial (44).

(43) Constituciones sinodales del obispado de Segovia del año 1648, Segovia, 1847, Título XII: "De decimis et oblationibus et primiciis"; M.L. CANDAU: El clero rural de Sevilla en el siglo XVII, Sevilla, 1994, pp. 241-260, ofrece datos interesantes sobre el diezmo en la campiña sevillana.

(44) M. BARRIO GOZALO: Estudio socio-económico..., pp. 98-101. 
¿Se pagan con exactitud los diezmos? Es difícil de contestar. No hay duda que se trata de una contribución soportable para los labradores acomodados, pero muy dura para los pequeños propietarios y muchos arrendatarios. Siendo invariables ciertos gastos generales, como la simiente para sembrar y los gastos de labranza; el diezmo resultaba muy gravoso en los años malos y en las tierras pobres. La reiterada prohibición que hacen las Sinodales de no descontar la simiente a la hora de diezmar, muestra la convicción del campesino de que una porción considerable de su cosecha de granos ya había diezmado el año anterior como simiente.

Muchos eran los artilugios y medios utilizados para esquivar o minorar el pago del diezmo, como pagar el diezmo de los granos de peor calidad, llevar las ovejas a esquilar a dehesas donde no se pagaba, trasladar la residencia a lugares donde los párrocos prometían tratarles con mayor indulgencia, etc. Sin embargo, la defraudación existente no parece que fuera muy grande hasta principios del siglo XIX. Al menos eso es lo que afirman Gonzalo Anes (45), Esteban Canales (46) y Pablo Fernández Albadalejo (47), entre otros; y yo mismo he podido comprobar para el obispado de Segovia, donde el año 1794 los granos diezmados representan el 9,88 por 100 de las cosecha obligada a pagar diezmo (48). En cambio, Ardit Lucas sospecha que existe "una resistencia apreciable al pago del diezmo en los últimos decenios del siglo XVIII" (49).

La recaudación de un impuesto tan extenso exigía una complicada organización. Cada parroquia formaba una unidad a efectos de percepción del diezmo y nombraba un "tercero o cillero" encargado de recoger y guardar los frutos decimales. Una vez que estaban almacenados en la cilla y que el párroco, de acuerdo con las declaraciones de los dezmeros y las anotaciones del tercero había formado las tazmias y las había leído en la misa mayor del domingo se procedía a su reparto entre los interesados. Los diezmos de granos se acostumbran a distribuir en el mes de septiembre y los de ganado en junio. En algunas diócesis como Lérida, Tortosa y otras más, no se hacían tazmías, sino que se repartían directamente entre los interesados.

"En el obispado de Tortosa - dice el obispo- no hay libros de tazmías, ni de cuenta y razón formal de la cosecha de diezmos, pues recogida en cada distrito por las personas que nombran los interesados se reparten en especie, dando a cada uno la porción que le corresponde, al respecto de la tercera, quarta o quinta parte porque se interesa, sin que para ello se lleve ni necesite más quenta que la verbal" (50).

(45) Las crisis agrarias en la España Moderna, Madrid, 1970, p. 163.

(46) "Los diezmos en su etapa final", en G. ANES, ed., La economía española al final del antiguo régimen, I: La agricultura, Madrid, 1982, pp. 105-187.

(47) La crisis del Antiguo Régimen en Guipüzcoa, 1766-1833, Madrid, 1975, pp. 315-316.

(48) M. BARRIO GOZALO: Estudio socio-económico..., pp. 104-106.

(49) "Recaudación y fraude diezmal en el siglo XVIII valenciano", en Estructuras agrarias y reformismo ilustrado en la España del siglo XVIII. Actas del Seminario de Segovia sobre Agricultura ellustraciốn èn España, septiembre 1988, Madrid, 1989, pp. 391-403.

(50) AHN, Consejos, leg. 4.181: Obispo de Tortosa a la Cámara. Tortosa 10 febrero 1774. 
La distribución de los diezmos, que inicialmente se hacía en tres tercios iguales -uno para los servidores de la Iglesia, otro para la fábrica y el tercero para el obispo-, con el paso del tiempo adquirió mayor complejidad, tanto por los dos novenos (tercias reales) concedidos al rey como por la inclusión de nuevos beneficiarios. De todas formas, como algo meramente referencial, pues son muchas las diferencias que existen de unas diócesis a otras, se puede indicar que en la mayor parte de Castilla, a excepción del reino de Granada (51), los diezmos se distribuían en tres tercios:

-Del primero se benefician los curatos y beneficios de libre provisión.

-El segundo se reparte entre las mesas episcopal y capitular.

-Y el tercero se distribuye entre los demás partícipes: tercias reales, fábricas, hospitales, etc.

Pero, junto a los eclesiásticos, también se benefician de los diezmos algunos particulares laicos, a los que se había cedido una parte o su totalidad en los siglos anteriores. Su cuantía, que es relativamente baja en Castilla (5,82\%), adquiere mayor importancia en Cataluña, como sucede en la diócesis de Urgell, donde los seglares se llevan la mayor parte de los diezmos de todas especies por razón de señores jurisdiccionales (52).

La evolución de los frutos decimales está determinada por el nivel de la cosecha de cada producto, por la exactitud en su abono, por la forma de administrar la casa excusada, por la abolición de las exenciones de pagar el diezmo en 1796 y la imposición del noveno decimal en 1800 .

La mala forma de diezmar, como después veremos, no se generaliza hasta los primeros años del siglo XIX; en cambio, la diferente forma de administrar la casa mayor dezmera o excusado que se opera en 1761 produce una disminución de la masa decimal próxima al 7 por 100 (53). La abolición de las exenciones de pagar diezmos decretada por Pío VI en 1796 provoca un incremento de los diezmos cercano al 5 por 100 , pero en 1801 Pío VII concede estos diezmos al rey Carlos IV. A su vez la concesión del noveno de todos los diezmos al monarca el año 1800 , a excepción de los percibidos por los beneficios eclesiásticos que con ello se quedarán incóngruos, provoca una disminución de los diezmos percibidos por la Iglesia cercana al 8 por 100 (54).

A pesar de estos y otros inconvenientes, las series decimales se consideran un buen indicador de la producción agraria y, por ello, son profusamente utili-

(51) Aquî los diezmos se dividían en nueve partes, de las que dos constituían las tercias reales. De las siete restantes, divididas en once, cuatro eran para el obispo, cuatro para los beneficios parroquiales, tres para dotación de los prebendados de la catedral, una para la fábrica y otra para los hospitales. Más información en M. GARZON PAREJA: Diezmos y tributos del clero de Granada, Granada, 1974, pp. 92-97.

(52) El obispo de Urgell informa a la Cámara el 13 de noviembre de 1773 (AHN, Consejos, leg. 4.181) que "en esta diócesis, a diferencia de otros territorios, está por los seculares la mayor parte de los diezmos de todas clases, de modo que de las tres cuartas partes se llevan las dos los excelentísimos señores Duque de Medinaceli, Duque de Hijar, Conde de Aranda y otros varios particulares. Todos por razón de señores jurisdiccionales, y aún las comunidades eclesiásticas gozan por este título sus diezmos y no por eclesiásticos...".

(53) A. ITURRIOZ: Estudio del Subsidio y Excusado (1561-1808), Logroño, 1987, pp. 185-262.

(54) M. BARRIO GOZALO: Estudio socio-económico..., pP. 132 y 166-172. 
zadas por los estudiosos de los fenómenos agrarios, de tal manera que disponemos de series más o menos completas para un buen número de regiones o provincias españolas (55). Si nos fijamos en el caso andaluz, estudiado por Ponsot (56), Benítez (57), Gámez (58) y Muñoz Dueñas (59), entre otros, y en los datos que yo aporto en el trabajo sobre la economía de los obispos andaluces (60), se aprecia un importante descenso de la masa decimal en el siglo XVII; una recuperación en el XVIII $(+16,5 \%)$, y una fuerte caída en el primer tercio del XIX $(-25 \%)$.

De todas formas, los diezmos suponían una fuente de ingresos para la Iglesia tan importante como la proveniente de la explotación de sus propiedades. Constituyen cerca del 40 por 100 de las entradas eclesiásticas y, a mediados del siglo XVIII, el Catastro de Ensenada valora los de la Corona de Castilla, con exclusión de las tercias reales, en 83.406.088 reales de vellón (61).

\subsection{Las primicias}

Con el nombre de primicias se entiende una parte de los frutos de la tierra y de los ganados que, a manera de tributo eclesiástico, se entregaba también a la Iglesia. Se introdujeron en la Iglesia desde antiguo, como práctica piadosa y voluntaria para contribuir al culto y en reconocimiento del dominio de Dios sobre todas las cosas, pero con la promulgación de las Decretales se hicieron obligatorias.

En España esta normativa adquiere valor civil al ser exigidas por el Código de las Siete Partidas, donde se ordena que los cristianos den primicias de los frutos que cogieren de la tierra y de los ganados que crien. La cuota que se debía pagar difiere mucho de unos lugares a otros, aunque la primera Partida dispone que no sea menos de la sexagésima parte de los frutos $(1,67 \%)$ y más de la cuadragésima $(2,50 \%)$.

Sin embargo, la haber muy pocos estudios locales o diocesanos sobre las primicias es difícil concretizar como se cumplía la normativa legal de carácter civil, pues las Constituciones Sinodales, por lo general, se limitan a decir que se

(55) Muchas de ellas se publicaron en las obras coordinadas por J. GOY y E. LE ROY LADURIE: Les fluctuations du produit de la dîme. Conjoncture décimale et domaniale de la fin du Moyen Age au XVIIIe siècle, París-La Haya, 1972; y' Prestations paysannies, dîmes, rente foncière et mouvement de la production agricole à l'époque préindustrielle, 2 vols., Paris-La Haya, 1982.

(56) "En Andalousie occidentale. Les fluctuations de la production du blé sous l'Ancien Régimen", en J. GOY y E. LE ROY LADURIE: Les fluctuations du produit de la dîme..., pp. 304 . 319; y Atlas de bistoria económica de la Baja Andalucía (siglos XVI-XIX), Sevilla, 1986.

(57) "Diezmos andaluces: series malagueñas del diezmo del trigo", en J. GOY y E. LE ROY LADURIE: Prestations paysannes, dîmes..., I, pp. 295-307.

(58) "Las tendencias de las producciones de trigo, cebada y maíz en la actual provincia de Málaga en el siglo XVIII", en AIHCA s. XVIII, Córdoba, 1983; y "Una o varias agriculturas en la Andalucía del siglo XVIII", en Estructuras agrarias y reformismo ilustrado..., pp. 79-87.

(59) El diezmo del obispado de Córdoba, 1750-1845, Córdoba, 1988.

(60) "Los obispos de Andalucía...", pp. 92-140.

(61) Los datos han sido tomados de GRUPO'75: La "renta nacional..." p. 199. 
paguen fielmente, sin concretizar la forma y modo de su abono como hace con los diezmos (62).

En el obispado de Segovia se exigían primicias de los cereales y, en algunos lugares, también del mosto y del queso. La cuota que labradores y cosecheros tenían que pagar estaba regulada por costumbre inmemorial y difería sensiblemente de unas zonas a otras. En unos arciprestazgos todo labrador que coge cinco fanegas paga media; en cambio, en otros se exigen primicias de grano en función de las yuntas de ganado que tengan, pagando por cada yunta una fanega de trigo y otra de cebada o centeno.

Pero ¿cuánto importan las primicias? A nivel general sólo conozco los datos que ofrece el Catastro de Ensenada para Castilla y su cuantía se sitúan en torno a los 5.077.290 reales de vellón, lo que supone el 6,09 por 100 del importe de los diezmos. En cambio, en el obispado de Segovia, de acuerdo con la valoración que se hace de los diezmos y primicias en 1775, éstas importan 265.391 reales, lo que representan el 9,46 por 100 del valor de los diezmos.

\subsection{El voto de Santiago}

El voto de Santiago era un tributo eclesiástico, surgido en plena Reconquista, a favor del arzobispo y el cabildo de Santiago. Su vigencia cronológica va del año 834, en que nace bajo el reinado de Ramiro I de León, hasta 1834 en que muere bajo la regencia de María Cristina por una ley de 6 de noviembre (63).

El avance espacial del voto sigue la marcha de la Reconquista y tiene su culminación en los reinados de los Reyes Católicos y Felipe II. En 1492, los Reyes Católicos imponen este tributo al recién conquistado reino de Granada, que después se conocerá con el nombre de "Voto viejo". Ahora bien, si en los reinos de Galicia, León y Castilla el producto de esta renta iba a manos del arzobispo y cabildo de Santiago, en Granada se hace una participación distinta', ya que un tercio de lo recaudado se destina al Hospital Real de Santiago, fundado en esas mismas fechas por Isabel y Fernando para la atención de los peregrinos.

A lo largo del siglo XVI se produce una ampliación del espacio sujeto al tributo, sin más razón justificativa que un deseo por parte de la iglesia de Santiago de incrementar sus rentas. Con escasa base documental, pero con una fuerte influencia en la Corte, el arzobispo y el cabildo compostelano consiguen que el resto de Andalucía y todo el territorio al sur del Tajo, incluyendo el reino de Murcia, sean obligados a pagar este gravamen, conocido como el "Voto nuevo de Santiago".

A pesar de los muchos pleitos que los pueblos de Andalucía mantuvieron contra esta imposición, a partir de 1573 su cobranza ya estaba consolidada y sus beneficios se distribuian entre el arzobispo y el cabildo. De esta forma, al finalizar el siglo XVI la imposición del voto afecta a la casi totalidad de la corona de Casti-

(62) Información sobre la cuota y beneficiarios de las primicias se hallan en las obras de $M$. BARRIO GOZALO: Estudio socio-económico..., pp. 140-145; M.L. CANDAU: El clero rural de Sevilla..., pp. 260-262; y PUEYO: Iglesia y sociedad zaragozanas..., pp. 357-367.

(63) Ha sido estudiado de forma exhaustiva por Ofelia Rey Castela en su tesis doctoral (El voto de Santiago en la España Moderna, Santiago, 1984), y la sigo en estas líneas. 
lla y, en concreto, a Galicia, tercio norte de Portugal, reino de León, mitades norte de Extremadura y occidental de Castilla la Vieja y la zona al sur del Tajo. Pero, las villas y lugares de los obispados de Toledo (zona norte del Tajo), Burgos, Palencia, Siguenza, Osma y Calahorra, se resisten a pagar el voto y mantienen un largo pleito en la iglesia de Santiago que el Consejo Real falló en 1628 en contra de la iglesia compostelana, descargando a aquellos pueblos de la obligación del voto, que jamás habían pagado.

La cuota que normalmente se paga consiste en media fanega de grano por cada labrador que tenga yunta propia, y en el caso de los pegujaleros la cuota baja a una cuartilla. De todas formas en las respuesta 16 y 17 del interrogatorio del Catastro de Ensenada se especifica la cantidad que se paga en cada lugar.

¿Cómo se administra este impuesto? En el caso del Voto Viejo, el administrador general saca a subasta pública los once partidos en que se distribuye el reino de Granada, arrendado cada uno de ellos al mejor postor. En el caso del Voto Nuevo, el amplísimo marco geográfico obliga a dividirlo en diez grandes distritos, situando al frente de cada uno un administrador que se encarga de arrendar anualmente el voto. El arriendo se efectúa en grano y no en dinero, y el administrador se ocupa de la venta del grano recaudado $y$, si fuera preciso, de su propia recaudación. Al frente de este organigrama se encuentra el administrador general, que siempre es un canónigo de la catedral compostelana, y desde 1615 cuenta con la apoyatura legal del sendos jueces protectores del voto en las Chancillerías de Valladolid y Granada.

El importe de los votos fluctúa al unísono de los precios, de manera que mientras en el período 1640-1699 suma una cantidad media anual de 761.830 reales de vellón, en los años 1700-1769 sube hasta 1.046 .048 reales. Pero de esta cantidad hay que deducir los gastos de administración, que suman un 9 por 100 y los que originan los pleitos que no alcanzan el 0,50 por 100 de los ingresos (64).

\subsection{Derechos parroquiales y limosnas}

La costumbre de los fieles de ofrecer oblaciones de pan, vino, carne o cera en algunas fiestas y, de forma especial, en los entierros y funerales, con el paso del tiempo fue exigida por los curas como obligatoria. Tanto es así que los aranceles vigentes en muchas parroquias señalan la ofrenda que los fieles deben hacer a la Iglesia, al cura y al sacristán, además de pagar al estipendio, por la celebración de determinados actos de culto (65). Cuantificar estos ingresos me parece imposible, al ser algo totalmente contingente, sujeto más a la costumbre de cada lugar que a una normativa jurídica. Bástenos saber que es una cantidad nada despreciable y, en el caso del clero parroquial, muy importante.

(64) Datos sobre los ingresos que los arzobispos de Santiago reciben por este concepto se pueden ver en M. BARRIO GOZALO: "Los obispos del reino de Galicia...", pp. 68-71.

(65) En la parroquia de Santiuste de Pedraza (Segovia) el arancel vigente en 1760 mandaba que en la celebración del matrimonio, además de los 12 reales del estipendio, se debía ofrecer "una espalda de carnero, un pan y una jarra de vino", todo ello para el cura. Otros ejemplos en M. BARRIO GOZALO: Estudio socio-económico..., p. 151. 
Otra fuente de ingresos para el clero era la proveniente de los derechos de estola. Desde antiguo se acostumbraba a dar alguna limosna al oficiante cuando administraba algún sacramento o dispensaba ciertos oficios del ministerio eclesiástico. Con el paso del tiempo esta práctica se sancionó como legítima e incluso obligatoria. $\mathrm{Y}$ así las Constituciones Sinodales, a la vez que recuerdan que la administración de los sacramentos debe ser gratuita, aceptan y sancionan con fuerza de ley la costumbre de llevar alguna cantidad por los servicios cultuales. Esta costumbre de adquirir fuerza de ley, pasa a ser regulada por una tasa o arancel, en el que se especifica el "estipendio" que se ha de abonar por las distintas prestaciones cultuales. Algunos autores, como Canga Argüelles, Pierre Vilar o Gonzalo Anes (66), para conocer la importancia económica de estos ingresos, ha estimado de forma aproximativa el número de misas, bautizos, casamientos y entierros que se celebraban y han llegado a la conclusión de que proporcionaban unos ingresos similares a los provenientes de los diezmos. Ahora bien, para comprender la significación económica que estos ingresos tienen para el clero parroquial basta el siguiente dato: el estipendio que los clérigos reciben por la celebración de la misa, y éste raro día les falta, es similar al salario que cobra un obrero cualificado en la ciudad de Segovia a mediados del setecientos, pero su importe sólo representa el 5 por 100 de los ingresos del clero parroquial de la diócesis segoviana en esa misma época" (67).

A estos conceptos habría que sumar las abundantes limosnas, en especie y en dinero, que muchas comunidades religiosas, sobre todo las de frailes medicantes "puros", reciben del pueblo. Su cuantía es tan grande para estos mendicantes que, juntamente con los ingresos provenientes de la actividad cultual y pastoral constituyen la base principal de su economía: en la diócesis de Segovia representan el 75 por 100 de sus ingresos (68) y en el reino de Sevilla suben hasta el 79,27 por $100(69)$.

Para concluir, se puede afirmar que las cifras que ofrece el Catastro de Ensena$\mathrm{da}$, a pesar de sus limitaciones, permiten estimar los ingresos fijos de la Iglesia de Castilla en unos 359.806.257 reales de vellón, lo que representa el 13,17 por 100 de la renta nacional. A ello habría que sumar el importe de los "adventicios" devengados por el ejercicio de la actividad cultural y pastoral, más las limosnas. Si estas cifras se comparan con la valoración de las rentas eclesiásticas de Castilla que se presentó en Roma en 1630 ( 70$)$, se observa un importante aumento, muy elevado en términos absolutos $(+241,21 \%)$ y más bajo en términos relativos $(+43 \%)$

(66) G. ANES: El Antiguo Régimen: Los Borbones, Madrid, 1975, p. 74.

(67) M. BARRIO GOZALO: "La Diócesis de Segovia en el siglo XVIII", en Antbologica Annua, 26-27 (1979-80), 715; ver también la obra de M.L. CANDAU: El clero miral de Sevilla..., pp. 262-268.

(68) M. BARRIO GOZALO: Estudio socio-económico..., pp. 649-658.

(69) A.L. LOPEZ MARTINEZ: La economía de las órdenes religiosas..., p. 124.

(70) ASV, Misc. Arm. I, vol. 90, f. 246: Valor de todas las rentas eclesiásticas... Año 1630. Esta "valoración" es similar a la que se encuentra en ASV, AN Madrid, vol. 80, ff. 55-57: Memorial que, bacia 1640, se dio a S.S. por parte del Estado Eclesiástico de estos reinos (Castilla y León), en que se liquida el valor de las rentas eclesiásticas y lo que pasa a S.M.C., donde se afirma que "aunque hoy no valen todas las rentas eclesiásticas de aquellos reinos 7 millones, se supone que valen 10 millones y 400.000 ducados, que es el valor que los ministros reales dan a las dichas rentas y lo que valieron el año de 1592, que fue cuando se hizo el último valor por mandato del Sr. Rey Felipe II". 


\begin{tabular}{cccc} 
Año & \multicolumn{2}{c}{ Importe } & $\begin{array}{c}\text { \% de la } \\
\text { Renta global }\end{array}$ \\
\cline { 2 - 4 } & Reales & Indice & Re \\
\hline 1630 & 114.510 .000 & 100,00 & 9,21 \\
1752 & 359.806 .257 & 314,21 & 13,17
\end{tabular}

Los datos anteriores se refieren a Castilla, pero si los extrapolamos a la Corona de Aragón, pues como dice Domínguez Ortiz (71), "no hay motivo para creer que en Aragón la situación fuera distinta en lo sustancial", no sería aventurado afirmar que el clero español percibía una parte importante de la renta global.

Pero, ¿en qué porción se beneficia la. Iglesia de la producción agraria? En opinión de Bartolomé Yun, a finales del siglo XVIII, la participación que los eclesiásticos de Castilla la Vieja y León tienen en el producto agrario por las rentas que obtienen y los diezmos que reciben, se eleva al 23 por 100 del producto total, lo que "significa un 30 por 100 del producto descontados los gastos de simiente y, quizá, entre un 30 y un 40 por 100 de los excedentes de comercialización, si se considera también el consumo interno de las comunidades" (72).

Este volumen de riqueza, sin embargo, estaba gravado por la presión fiscal del Estado y de la Curia romana. Aunque a mediados del seiscientos los eclesiásticos afirman reiterativamente que el Estado recibe más de la mitad de las rentas eclesiásticas (73) y, un siglo después, el marqués de la Ensenada reconoce que, si se exigiesen según las concesiones, las prestaciones eclesiásticas serían tan gravosas que los clérigos pagarían el doble en proporción con los seglares (74), lo más probable es que su cuantía no supere el 18 por 100 , pues sus partidas fijas suman algo menos de 19 millones de reales de vellón, distribuidos de la forma siguiente (75):

(71) Sociedad y Estado en el siglo XVIIl español, Barcelona, 1976, p. 360.

(72) "Ingresos, formas de distribución del producto agrario y cambio social en Castilla la Vieja y León en el siglo XVII", Estructuras agrarias y reformismo ilustrado..., p. 496.

(73) En el Memorial que la Iglesia de Castilla presentó a Urbano VII hacia 1640 (ASV, AN Madrid, vol. 80, ff. 55-57), se afirma que las rentas eclesiásticas de Castilla y León importan 114.400 .000 reales de vellón, y de ellos pasan al estado 55.285.000, es decir el 48,32 por 100, por los siguientes conceptos:

Tercias Reales

Mesas Maestrales

Mesada eclesiástica

Subsidio de Galeras

Excusado

Millones

Encomiendas Ordenes Militares

Pensiones sobre las Mitras

Otros conceptos

Total

Cantidades similares se ofrecen en la Contradicción que se hizo por el procurador general del Estado eclesiástico en 1662, extractada por A. DOMINGUEZ ORTIZ, "La desigualdad contributiva' en Castilla durante 'el siglo XVII", en Anuario de Historia del Derecho Español, 21-22 (1951-52), 1.244-1.246.

(74) "Informe del marqués de la Ensenada a Fernando VI", en Semanario Erudito, XIII, Madrid, 1788 , p. 278.

(75) ASV, AN Madrid, vol. 131, ff. 45-48. 


\begin{tabular}{|c|c|c|}
\hline Excusado & 2.750 .000 & reales \\
\hline Mesada eclesiástica & 526.320 & \\
\hline Millones & 7.150 .000 & \\
\hline Pensiones sobre mitas & 2.319 .153 & \\
\hline Subsidio de galeras .... & 4.620 .000 & \\
\hline Otros conceptos .... & 1.622 .974 & " \\
\hline
\end{tabular}

La Curia romana también se beneficiaba de una parte importe de las rentas eclesiásticas españolas, al menos hasta la firma del Concordato de 1753. A modo de ejemplo diré que, durante el periodo 1711-1720, el importe de las pensiones, annatas, quidenios, etc., que se pagaron a Roma ascendió a 6.919.297 reales de vellón al año (76), a lo que habría que sumar los derechos que se pagaban a la Dataría y Cancillería Apostólica por la provisión de beneficios, espolios y vacantes de las mitas, etc. (77).

\subsection{Distribución de las rentas eclesiásticas}

La distribución de esta riqueza entre los miembros del estamento eclesiástico, aunque era muy desigual, respondía de alguna forma a los presupuestos socioreligiosos vigentes en la sociedad de la época. El cuadro quinto muestra la forma de distribuir las rentas eclesiásticas en los obispados de Cádiz (78), Málaga (79) y Segovia (80):

\section{CUADRO 5 \\ Distribución de las rentas eclesiâsticas (expresado en \%)}

\begin{tabular}{|c|c|c|c|}
\hline Beneficiario & Cádiz & Málaga & Segovia \\
\hline Beneficiados y curas & 2,06 & 15,80 & 28,15 \\
\hline Cabildo catedral .......................... & 16,45 & 13,57 & 10,77 \\
\hline Cabildo colegial . & - & 2,94 & - \\
\hline Capellanías y cofradías ............ & 20,33 & 15,51 & 12,59 \\
\hline Fábrica iglesias ............................ & 6,59 & 10,51 & 8,80 \\
\hline 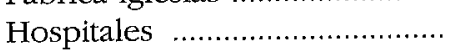 & - & 2,18 & 4,69 \\
\hline Monasterios y conventos ......... & 16,28 & 14,06 & 21,81 \\
\hline 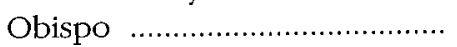 & 10,32 & 15,03 & 6,93 \\
\hline
\end{tabular}

(76) AEESS, leg. 300.

(77) Ver el estudio de Q. ALDEA: "Iglesia y Estado en la España del siglo XVII", en Miscelanea Comillas, 36 (1961) 143-540 (en especial las pp. 255-346).

(78) A. MORGADO GARCIA: Iglesia y Sociedad..., p. 247. Los datos se refieren al año 1799.

(79) R. BENITEZ: "Las rentas eclesiásticas del obispado de Málaga...", p. 128. Las cifras corresponden al quinquenio 1651-1655.

(80) M. BARRIO GOZALO: Estudio socio-económico..., p. 160. La valoración de las rentas se refiere al quinquenio 1771-1775. 
Obras Pías

Sacristanes

Otros

$\begin{array}{ccc}26,83 & - & 2,49 \\ - & 2,16 & 3,77 \\ 1,14 & 8,24 & -\end{array}$

Los obispos son los eclesiásticos que relativamente controlan el mayor volumen de riqueza, pues se benefician de cerca del 12 por 100 de las rentas eclesiásticas (81). Sin embargo, las grandes diferencias del territorio y población de las diócesis, así como la distinta participación en los diezmos (capítulo mayoritario de sus ingresos), establece gran desigualdad entre las rentas episcopales, hasta el punto que entre la rica Toledo y los pobres de Jaca, Solsona o Barbastro esta diferencia supera ampliamente el 4.000 por 100 . Vamos a verlo con más detalle. En la primera mitad del setecientos, el importe de la renta líquida de los 55 obispos residenciales existentes se eleva a 14.831 .665 reales de vellón, pero las doce mitras más ricas acaparan' el 56,72 por 100 de esta cantidad, destacando sobremanera las "muy ricas" de Toledo (15,26\%), Sevilla (7,46\%) y Valencia (6,57\%). En cambio, las quince mitras' "pobres" sólo disfrutan del 6,87 por 100 , distribuyéndose el 36,41 por 100 restante entre las otras 28 mitras (82).

También los cabildos de canónigos acaparan un importante volumen de riqueza. En Málaga, a mediados del XVII, representa el 13,57 por 100 de las rentas eclesiásticas de la diócesis, el 10,77 por 100 en Segovia un siglo después (84) y el 16,45 en Cádiz al finalizar la centuria (85). Esta riqueza se distribuye entre los miembros del cabildo de acuerdo con el sistema de reparto establecido, materializando así la desigualdad jurídica con la económica, pues mientras los ingresos de algunas dignidades del cabildo de Toledo sobrepasan los 100.000 reales al año, los de un racionero del mismo cabildo apenas llegan a los 7.000 (86). En otros cabildos de tipo medio, como el de Segovia, aunque las diferencias no son tan exageradas, siguen siendo igual de importantes, pues si los ingresos de alguna dignidad superan los 20.000 reales, los del racionero se sitúan en poco más de 4.000 (87).

El bajo clero secular, a pesar de las grandes diferencias existentes entre sus miembros, mantenía una situación de privilegio dentro del conjunto de la población. Los ingresos del clero parroquial, provenientes de propiedades, diezmos y emolumentos adventicios, proporcionaba a la mayor parte de los párrocos una dotación suficiente, pues sus ingresos medios se asemejan a los que perciben los administradores de las rentas reales (unos 3.000 reales de vellón al año). Pero

(81) De acuerdo con la valoración de las rentas eclesiásticas del clero secular que se hace hacia 1630 (ASV, Misc. Arm. I, vol. 90, f. 246 r.), los obispos de los reinos de la Corona de Castilla controlan el 16,37 por 100 de estas rentas.

(82) Mayor información sobre la jerarquía de las rentas episcopales en M. BARRIO GOZALO: "La economía de los obispos en la España del Antiguo Régimen (1556-1834)", en Fra Spazio $e$ Tempo..., I, pp. 52-75.

(83) R. BENITEZ: "Las rentas eclesiásticas del obispado de Málaga...", p. 128.

(84) M. BARRIO GOZALO: Estudio socio-económico..., p. 160.

(85) A. MORGADO GARCIA: Iglesia y Sociedad..., p. 247.

(86) ASV, Fondo Consistoriales, PC, vol, 145; f. 564 r.

(87) Archivo de la Catedral de Segovia, D-1.244: Valores de las piezas eclesiásticas de este obispado de Segovia... en los años 1725-1729. 
también aquí las diferencias son enormes, pues mientras la renta de algunos párrocos supera los 30.000 reales, la de otros muchos no llega a los 1.000. Esta situación determinó que el Consejo de Castilla encarga a los obispos la confección de un Plan de reforma beneficial, que suprimiera las parroquias muy pequeñas y creara otras nuevas, elevando la congrua (ingresos mínimos) de los párrocos a 4.000 reales (88).

La situación económica del elevado número de clérigos sin cura de almas existente, aunque era bastante inferior a la de los párrocos, parece que no era tan miserable como se suele afirmar, pues muchos capellanes -estrato más bajo del clero secular- además del producto de la capellanía, tenían algún otro patrimonio.

El clero regular acumula un importante volumen de riqueza en la mayoría de las diócesis españolas. A mediados del setecientos representa el 35 por 100 de las rentas eclesiásticas en la de Barcelona (89), el 22 por 100 en la de Segovia (90) y el 27 por 100 en el reino de Sevilla (91). En el caso de los monacales esta riqueza proviene de las extensas propiedades rústicas que poseen, en muchos casos explotadas directamente por los monjes, lo que hace que sus ingresos se incrementen considerablemente durante la primera mitad del setecientos en consonancia con el movimiento de los precios agrícolas y de la renta; en cambio, la de los mendicantes "puros", constituida básicamente por ingresos de carácter adventicio, sufre un gran deterioro desde mediados del setecientos. Aunque el porcentaje de cada uno de los conceptos que componen las rentas del clero regular varía sensiblemente de unas diócesis a otras, los datos que ofrezco a continuación para las diócesis de Barcelona y Segovia, y el reino de Sevilla pueden servir de orientación (92):

\begin{tabular}{lccr} 
Concepto & Barcelona & Segovia & Sevilla \\
\hline Bienes raíces & 40,52 & 33,65 & 59,75 \\
Censos y juros & 46,53 & 12,89 & 21,47 \\
Diezmos & 12,68 & 17,45 & 3,96 \\
Adventicios & 0,27 & 36,01 & $\mathbf{1 4 , 8 2}$
\end{tabular}

(88) M. BARRIO GOZALO: "Las condiciones materiales del clero parroquial del obispado de Segovia en el siglo XVIII, I: Normativa legal o congrua clerical", en Investigaciones Históricas, 11 (1991) 9-34; y "II: La realidad de los ingresos y los gastos", en Ibídem, 12 (1992), 113-138. Estos datos que son válidos para el obispado de Segovia quizás no lo sean tanto para Cádiz (A. MORGADO GARCIA: Iglesia y Sociedad..., p. 135), Teruel (J.M. LATORRE CIRIA, "El clero del obispado de Teruel en 1753", en Aragonia Sacra, VI, 1991, 113-149), Sevilla (M.L. CANDAU, El clero rural de Sevilla..., pp. 277-310) o Zaragoza (P. PUEYO: Iglesia $y$ Sociedad..., pp. 196-226).

(89) E. CANALES GILI: "Las rentas de la Iglesia en vísperas de la revolución liberal: el ejemplo de la diócesis de Barcelona", en Industrialización y nacionalismo. Análisis comparativo. Actas del I Coloquio Vasco-Catalán de Historia, Bellaterra, 1985, p. 309.

(90) M. BARRIO GOZALO: Estudio socio-económico..., p. 821.

(91) A.L. LOPEZ MARTINEZ: La economia de las órdenes religiosas..., p. 106.

(92) Los datos han sido tomados de los trabajos de Canales Gili (Barcelona), Barrio Gozato (Segovia) y López Martínez (Sevilla), citados en las notas anteriores. 
Por último, no se debe olvidar que una parte importante de las rentas eclesiásticas estaba asignada a las fábricas de las iglesias y a las múltiples instituciones benéfico-sociales que se encuentran distribuidas por toda la geografía española.

\section{LA CRISIS DEL SISTEMA Y LA SUPRESION DEL PODER ECONOMICO DE LA IGLESIA}

El poder económico de la Iglesia es puesto en entredicho en el siglo XVIII, pues los ilustrados proclaman el retorno al modelo de una Iglesia pobre en bienes materiales. En esta ilusión desamortizadora alternan motivos espirituales de auténtica reforma, con los económicos y sociales de lucha contra la desigualdad y los privilegios, así como el deseo de incluir la riqueza inmueble de la Iglesia en el tráfico fiscalizado, sin olvidar los intereses políticos de devolver al monarca la regalía del control de trasferencia sobre algo que le pertenece por los derechos inherentes a su soberanía.

En primer lugar, el problema de la amortización eclesiástica se agrava en la primera mitad del setecientos, porque "la langosta de frailes ya se han cargado con todas las mejores haciendas" (93), ante el descenso de los réditos de censos (1705) y de los juros (1727), según afirma el fiscal del Consejo de Hacienda en 1765:

"La baja de los censos y juros (...) ha dado lugar a que las manos muertas, en lugar de imponer censos, se hayan aplicado mucho a comprar en este siglo con preferencia las tierras de raiz, aumentando desmedidamente las labranzas de los regulares..." (94).

El problema de la amortización eclesiástica que se había tratado en diferentes ocasiones por los Consejos de Castilla (1677), Aragón (1703) e Indias (1705) (95), e incluso fue objeto de discusión en las negociaciones previas a los concordatos de 1717 (96) y 1737 (97), nunca llegó a plantearse tan seriamente como en 1764, cuando el fiscal de Hacienda, don Francisco Carrasco, presentó un proyecto de ley general de amortización eclesiástica ante el Consejo de Castilla (98).

(93) AGS, Estado, leg. 6.096: Grimaldi a Tanucci, San Ildefonso 25 septiembre 1764, donde dice que "en el Consejo se está tratando ahora de los medios para evitar que los bienes raíces entren en poder de manos muertas y no dudo que resulte providencia favorable".

(94) ASV, AN Madrid, vol. 170, n.. 6: Suplemento a la respuesta dada por el fiscal de Hacienda sobre que se ponga limite a la adquisición de manos muertas. Madrid 16 de noviembre de 1765.

(95) Ibídem, n. 4: Parecer del Consejo Real de Castilla sobre el establecimiento de la Ley de Amontización propuesta por el fiscal de él y del de Hacienda. Madrid 18 julio 1766.

(96) J. FERNANDEZ ALONSO: "Un período en las relaciones entre Felipe V y la Santa Sede (1709-1714)", en Antbologica Annua, 3 (1955), 71-78.

(97) El resultado fue el art. 8. ${ }^{\circ}$ del Concordato. Ver texto en A. MERCATI: Raccolta di concordati tra la autoritá civile e la Santa Sede, I, Citá del Vaticano, 1954, p. 324, reproducido en castellano en la Novísima Recopilación, libro I, tít. 5, leyes 14 y 15.

(98) Ejemplares del proyecto, minutas y diferentes representaciones se encuentran en el ASV, $A N$ Madrid, vol. 170. Sobre él tema ver los estudios de B. CLAVERO SALVADOR: "Derecho de la amortización y cultura de la Ilustración", en Estructuras agrarias y reformismo ilustrado..., pp. 331-347; y J. FERNANDEZ ALONSO: "El Tratado de la Regalía de Amortización de Campomanes y el primer proyecto de ley general de amortización a través de los despachos de la Nunciatura", en Hispania Sacra, 11 (1958), 65-81. 
$\mathrm{Al}$ año siguiente, don Pedro Rodríguez de Campomanes, fiscal del Consejo de Castilla, publica su Tratado de la regalia de amortización, que tuvo un éxito inmediato y se convirtió desde el primer momento en el manual indiscutible de los regalistas, defendiendo una ley que pusiera freno a las adquisiciones de los eclesiásticos que, al no tener que pagar diezmos ni tributos de las cosechas, contaban con grandes ventajas para adquirir bienes raíces pues,

"aun quando las Comunidades compren a mayor precio las herencias raices de los seglares y den un tercio más de capital, nada pierden, porque lo indemnizan a costa de las demás clases del Reyno, (...); y así se llevan las mejores haciendas y fincas del Reyno, como la experiencia diaria nos lo manifiesta y lo decía el clero..." (99).

El Secretario de Estado, Grimaldi, informa que los consejeros de Castilla podrán dar su dictamen con toda libertad, porque el rey, a pesar de estar convencido de que es necesario poner remedio a las ilimitadas adquisiciones de los eclesiásticos, se mantiene al margen del proyecto, a fin de que todo discurra por los términos de la más estricta justicia y la resolución que se tome cuente con el total apoyo del Consejo y "cierre las puertas de la queja y de la murmuración a los que tienen interés contrario y a los que piensan como ellos por ignorancia o falsa piedad" (100).

A pesar de que tanto Grimaldi como Campomanes creian que la ley de Amortización era justa y necesaria, y pensaban que los argumentos del "pobre" Sierra no estaban en consonancia "con las luces de este siglo", lo cierto es que los razonamientos de este "pobre" fiscal convencieron a la mayor parte de los miembros del Consejo, que rechazaron el proyecto por diez votos contra seis (101).

A pesar del rechazo del anterior proyecto, la amortización eclesiástica continuaba siendo un problema y una tentación para los gobernantes. El 21 de agosto de 1795, un Real Decreto ordena que las manos muertas paguen el 15 por 100 de todos los bienes que adquieran (102), y en 1798, con autorización pontificia, se inicia la desamortización eclesiástica con la venta de los bienes raíces de hospitales, hospicios, casas de misericordia, memorias, obras pías y patronatos de legos. Proceso que se alarga hasta 1808 en que la Junta Central manda suspender las ventas (103).

(99) P. RODRIGUEZ DE CAMPOMANES: Tratado de la regalia de amortización..., Madrid, 1765 (reimp. Madrid, 1975), p. 276. Una buena exposición del tema en F. TOMAS Y VALIENTE: Gobiemo e instituciones en la España del Antiguo Régimen, Madrid, 1982, pp. 287-316.

(100) AGS, Estado, leg. 6.099: Grimaldi a Tanucci, Aranjuez 1 abril 1766.

(101) ASV, AN Madrid, vol. 170, n. 4: Parecer del Consejo Real de Castilla sobre el establecimiento de la Ley de Amortización..., Madrid, 18 julio 1766.

(102) Novísima Recopilación, Libro I, tít. 5, ley 18.

(103) Ibídem, ley 22. Ver los estudios de R. HERR, "Hacia el derrumbe del Antiguo Régimen. Crisis fiscal y desamortización bajo Carlos IV", en Moneda y Crédito, 118 (1971), 37-100; "El significado de la desamortización en España", en Moneda y Crédito, 113 (1974), 55-94; y "La redistribution de la térre para la vente des propietés de mainmorte en Espagne, 17981808", en Annales E.S.C., 29 (1974) 215-288. 
Con la entrada de los franceses en España y la instauración de la monarquía nepoleónica, los regulares reciben el primer ataque frontal y se consuma la primera exclaustración y la desamortización de sus bienes (104). Política que, al menos en parte, es continuada por las Cortes de Cádiz. Frenado el golpe con la restauración fernandina, los liberales restablecen las medidas anteriores con el triunfo' constitucional de 1820 (105). Al finalizar el año 1823, al restaurarse el absolutismo, Fernando VII anula las medidas del Trienio y los regulares vuelven a sus conventos y se les devuelven sus bienes. Sin embargo, la semilla estaba echada y, así, cuando los liberales vuelven de nuevo al poder, a la muerte de Fernando VII, dan el golpe definitivo y no sólo decretan la supresión de los conventos de regulares y la expropiación de los bienes del clero regular (1836), sino también la desamortización de los bienes del clero secular (1837), consumado la aniquilación del poder económico de la Iglesia (106).

En segundo lugar, a medida que avanza el siglo XVIII, se observa un deterioro progresivo en el modo de diezmar y una impotencia cada vez mayor de los eclesiásticos para corregir los defectos. Si a mediados del siglo XVII los curas se quejan de que la amenaza de las cesuras eclesiásticas van perdiendo efectividad y "se las tragan como si no tuvieran alma", al comenzar el siglo XIX los eclesiásticos se ven impotentes para remediar un abuso tan antiguo, aunque acentuado en los últimos tiempos por "el abatimiento de la religión, las máximas anticristianas que se han propagado" y porque no hay quien castigue las infracciones de esta ley sagrada, pues los que tienen autoridad para hacerlo son los mismos violadores de ella. Pero lo más grave no era el hecho de la resistencia campesina a pagar los diezmos, sino que se discutiera el propio derecho de la Iglesia a exigirlos (107). Además, estas ideas llegan por medio de la prensa hasta los pueblos más remotos. Un ejemplo. En Herrera del Duque (Badajoz) durante las fiestas de mayo de 1808 se organiza una parodia de catequesis en la plaza mayor y un hombre, montado en un burro, "a voz de pregonero", pregunta al público:

(104) J. MERCADER RIBA: "La desamortización en la España de Josẹ́ Bonaparte", en Hispania, 32 (1972), 587-616.

(105) M. REVUELTA: Politica religiosa de los liberales en el siglo XIX. Trienio Constitucional, Madrid, 1973.

(106) G. RUEDA: La desamortización de Mendizábal y Espartero en España, Madrid, 1986, recoge una extensa bibliografía sobre el tema.

(107) Resulta difícil precisar la cronología y el ritmo de la inobservancia de la obligación de diezmar. No obstante, Esteban Canales ("Los diezmos en su etapa final", pp. 128-168) ha reunido las suficientes evidencias para poder establecer que no puede hablarse de prácticas defraudatorias masivas hasta la guerra de la Independencia y que el proceso tendió a acelerarse desde el momento en que los gobernantes del Trienio decidieron reducir el diezmo a :medida que aumentaba la presión fiscal sobre los productos agrarios. Quizás en la España de la periferia este proceso comenzó con anterioridad, como apunta Ardit ("Recaudación y fraude decimal en el siglo XVIII valenciano", en Estructuras agrarias y reformismo ilustrado..., pp. 391-410) 'para el caso valenciano. 
"Creéis que los diezmos son para mantener putas los que arrastran conches en Toledo y a los zánganos de los curas? Sí, creo (respondían a coro los presentes)" (108).

Por otra parte, las medidas adoptadas, en relación con los diezmos, por las Cortes de Cádiz de 1810-1814, por el gobierno de José I y por las Cortes de 1821 influyen de forma decisiva en que los dezmeros pierdan sus escrúpulos y se resistan al pago de los diezmos, a pesar de las circulares que los obispos publican sobre su obligatoriedad y de que la real orden de 1 de junio de 1817 disponga que los diezmos se paguen "con exactitud y religiosidad".

Después del decreto del 29 de junio de 1821, en que se redujo a la mitad el pago de todos los diezmos y primicias, la quiebra fue total. La sátira anticlerical prolifera y a través de un lenguaje socarrón y lleno de desenfado se critica la "explotación" que los eclesiásticos hacen de los recursos de los campesinos con el cobro de los diezmos y rentas que esquilman el fruto del labrador, resaltando las sabias medidas tomadas por las Cortes:

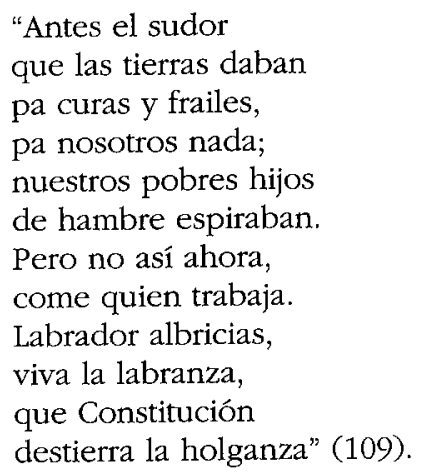

El restablecimiento de la obligatoriedad del pago íntegro no solucionó el problema y aumentó el clamor del estado eclesiástico ante el poco rigor con que se pagaba, según se reconoce en la circular de 14 de diciembre de 1826 , donde se señala que la defraudación era "escandalosa por efecto de la desmoralización general de los pueblos, producida por la libertad y desenfreno con que en las últimas épocas de revolución se habían difundido doctrinas erróneas y contrarias a la Iglesia y al Trono" (110).

La difusión de esta mentalidad explica que las Cortes no tuvieran excesivos problemas para aprobar la ley de supresión del diezmo, aunque no iba a ser tan

(108) Archivo Diocesano de Toledo, Borbón, leg. 55. Párroco de Herrera del Duque a la Curia. Herrera 2 junio 1808. Citado por L. HIGUERUELA: La diócesis de Toledo durante la guerra de la Independencia Española, Toledo, 1982, p. 183.

(109) Estas y otras muchas letrillas se pueden ver en las hojas que se imprimen en Segovia el año 1820 en la Imprenta de Espinosa y se conservan en el ADSg, Despacho Ordinario, Año 1820.

(110) Decretos de Fernando VII, XI, pp. 221-226. 
fácil desprenderse de él. Junto a la ley que lo abolía se tuvo que promulgar su continuación durante un año. Y como ya había ocurrido en el Trienio, la dificultad de asegurar por otros medios las atenciones a que hacía frente el diezmo retrasó la solución definitiva hasta 1841, en que por fin se firmó el acta de defunción de un impuesto que en muchas partes ya había muerto por agotamiento.

El antiguo régimen ha muerto y el mundo rural se ve liberado de entregar a la Iglesia una parte importante de su cosecha. Ya no hay que pagar diezmos, ni primicias ni voto de Santiago. Tampoco rentas, censos y otros derechos, porque los señoríos se han suprimido y los bienes muebles e inmuebles de la Iglesia han sido desamortizados. Sólo quedan los derechos de estola o pie de altar que los campesinos han de abonar a los curas por los servicios religiosos prestados. El ideal ilustrado del retorno a una Iglesia pobre en bienes materiales parecía hacerse realidad.

Por fin, el labrador puede cantar albricias, porque el sudor de la tierra ya no es "pa curas y frailes" sino para quien la trabaja. Pero el júbilo se acaba pronto, porque los compradores de bienes eclesiásticos siguen chupando el sudor de los campesinos que cultivan la tierra. 